Ekonomia - Wroclaw Economic Review 23/2 (2017)

Acta Universitatis Wratislaviensis

No 3770

DOI: 10.19195/2084-4093.23.2.4

\author{
Mikołaj Mielczarek \\ Uniwersytet Ekonomiczny w Poznaniu \\ mikolaj.mielczarek@ue.poznan.pl
}

\title{
Wpływ współczesnego \\ kryzysu ekonomicznego \\ na stan finansów publicznych \\ państw Grupy Wyszehradzkiej
}

Artykuł nadesłany: 10 listopada 2016 r.; artykuł zaakceptowany: 21 lutego 2017 r.

JEL Classification: E62, G01, H61, H62, H63

Keywords: economic crisis, fiscal pact, public finance, state budget, public debt

\begin{abstract}
The impact of contemporary economic crisis on public finances of the Visegrad Group

The article attempts to assess the state of public finances of the Visegrad Group (V4) during the contemporary economic crisis. At the beginning there are shown two faces of the economic crisis in the European Union and that this crisis firstly took the form of a banking crisis, and next extend to the public finance sector. Analysis of GDP proved that when we have crisis in the European Union in all V4 countries there has been a decline in the volume of GDP, and in the next years there were rather its growth. Analysis of the budget deficit showed that in 2008-2015 the V4 countries had problems in complying with the deficit below $3 \%$ of GDP. At the same time analysis of public debt showed that as a result of the economic crisis public debt in the Visegrad Group had a tendency to rather increase, but in the Czech Republic, Poland and Slovakia, it was less than $60 \%$ of GDP, while in Hungary exceeded $71 \%$ of GDP.
\end{abstract}

\section{Wstęp}

Rok 2009 był w Unii Europejskiej (UE) przełomowy, gdyż wtedy właśnie na jej terytorium pojawił się współczesny kryzys ekonomiczny, który miał swoje początki w Stanach Zjednoczonych. W pierwszej kolejności kryzys ekonomiczny przyjął w UE i jej państwach członkowskich formę kryzysu sektora bankowego. Wiele 
znanych banków europejskich, jak chociażby Fortis, musiało stawić czoła problemom z wypłacalnością, czego następstwem stało się ogłoszenie upadłości przez większość z nich. Państwa UE udzielały swojego wsparcia finansowego na rzecz banków zagrożonych upadłością, co skutkowało zwiększeniem wydatków budżetowych. Podejmowane działania przyczyniły się do pojawienia na przełomie lat 2011 i 2012 nowej formy współczesnego kryzysu ekonomicznego, czyli kryzysu finansów publicznych. Celem artykułu jest przedstawienie problemu kondycji sektora finansów publicznych w państwach Grupy Wyszehradzkiej.

Na podstawie literatury krajowej i danych Eurostatu zbadano wpływ współczesnego światowego kryzysu ekonomicznego na wielkość deficytu budżetowego oraz zadłużenie publiczne w Polsce, Czechach, na Słowacji i Węgrzech. W okresie kryzysu ekonomicznego zmianie ulegają priorytety polityki gospodarczej państw, mianowicie odchodzi się od ścisłego przestrzegania dopuszczalnego poziomu deficytu budżetowego na rzecz pobudzania gospodarki za pomocą odpowiednich pakietów antykryzysowych. Powoduje to, że zmniejszeniu ulegają często wpływy budżetowe, a zwiększają się wydatki z budżetu państwa. Dlatego też państwa Grupy V4 miały w latach 2009-2015 problem z utrzymaniem deficytu budżetowego na poziomie niższym niż 3\% PKB, a jednocześnie współczesny kryzys ekonomiczny wpłynął na zwiększenie ich zadłużenia publicznego.

Artykuł składa się z czterech części i zakończenia. W pierwszej części został ogólnie scharakteryzowany kryzys ekonomiczny w Unii Europejskiej. W drugiej części przedstawiono krótko historię Grupy Wyszehradzkiej oraz poziom PKB poszczególnych państw wchodzących w jej skład. W trzeciej części omówiono sytuację budżetową państw V4. W części czwartej analizie poddano poziom zadłużenia publicznego tych państw. W zakończeniu dokonano oceny przeprowadzonych badań.

\section{Dwa oblicza kryzysu ekonomicznego w Unii Europejskiej}

Współczesny kryzys ekonomiczny ma swoje początki w Stanach Zjednoczonych. Za jego główną przyczynę można uznać przewartościowanie kredytów subprime. Doprowadziło to do załamania się amerykańskiego rynku nieruchomości, czego skutkiem było między innymi pogorszenie sytuacji tamtejszego sektora bankowego. Przesłanki świadczące o nadchodzącym kryzysie pojawiały się wcześniej, ale ich niewłaściwa interpretacja doprowadziła do wybuchu w 2007 roku kryzysu ekonomicznego, który porównywany jest przez ekonomistów z Wielkim Kryzysem lat 1929-1933. We wrześniu 2008 roku upadł czwarty co do wielkości bank inwestycyjny Lehman Brothers, co spowodowało, że kryzys rozprzestrzenił się na cały świat. Do Unii Europejskiej docierały już wtedy sygnały kryzysowe, a efektem było pojawienie się w 2009 roku kryzysu w państwach członkowskich. 
Współczesny kryzys ekonomiczny w UE przyjął dwa oblicza. W pierwszej kolejności dotknął on sektora bankowego w państwach unijnych, zatem objawił się jako kryzys bankowy. W późniejszym okresie zjawiska kryzysowe przeniosły się na sferę zadłużania państw, dlatego też w tym aspekcie możemy mówić o pojawieniu się kryzysu finansów publicznych. Skoro kryzys zadłużeniowy państw pojawił się po kryzysie bankowym, to można przyjąć, że oba te kryzysy są ze sobą ściśle powiązane, a jeden wywodzi się w zasadzie z drugiego.

System bankowy w Unii Europejskiej mocniej odczuł skutki obecnego kryzysu aniżeli w Stanach Zjednoczonych. Dowodem na to jest chociażby fakt, że amerykański system bankowy udało się ustabilizować pod koniec 2009 roku, natomiast w Europie kryzys trwał nadal. Oczywiście można zauważyć, że zjawiska kryzysowe pojawiły się w UE dopiero w 2009 roku, ale pomoc finansowa była już wcześniej kierowana do banków europejskich. Pomoc taka była spowodowana zależnościami występującymi pomiędzy bankami europejskimi a amerykańskimi. Europejski system bankowy jest wciąż narażony na zjawiska kryzysowe, mimo że banki europejskie w przeciwieństwie do swych amerykańskich odpowiedników prowadziły w przeszłości nieco bardziej odpowiedzialną politykę finansową (Mesjasz 2012, s. 118; Firlej 2011, s. 185-186). Dzięki temu przetrwały one najtrudniejszą fazę kryzysu, jednak nie spowodowało to wzrostu stabilności systemu bankowego.

Kryzys bankowy w Unii Europejskiej nie osiągnąłby prawdopodobnie takich rozmiarów, gdyby europejskie banki zostały poddane szczegółowej ocenie swej kondycji w taki sposób jak banki amerykańskie (Mesjasz 2012, s. 118). Przeprowadzenie takiej oceny kondycji banków na wczesnym etapie kryzysu prawdopodobnie przyczyniłoby się do wzrostu poziomu zaufania inwestorów do unijnego sektora bankowego. Tak właśnie stało się w Stanach Zjednoczonych, gdzie już na początku kryzysu przeprowadzono ocenę kondycji banków i wprowadzono programy naprawcze. Dzięki temu po zamknięciu najsłabszych banków i jednoczesnym zastosowaniu odpowiednich narzędzi naprawczych w pozostałych bankach wróciło zaufanie inwestorów do amerykańskiego sektora bankowego. Natomiast w Europie pierwsze badania kondycji finansowej banków przeprowadzono dopiero pod koniec 2009 roku, ale ich wyniki okazały się nieprzydatne, gdyż były zbiorcze i nie odzwierciedlały faktycznej sytuacji ekonomicznej poszczególnych instytucji finansowych.

Ważną kwestią, którą warto poruszyć, w przypadku kryzysu bankowego w UE jest problem zaufania inwestorów do rynku finansowego. Współczesny kryzys finansowy, który wpłynął na unijny system bankowy, był początkowo związany z kryzysem na rynku kredytów subprime w Stanach Zjednoczonych, a później z kryzysem zadłużeniowym w strefie euro (Lepczyński, Penczar 2012, s. 402-403). Zaburzenia na amerykańskim rynku kredytów hipotecznych doprowadziły do spadku zaufania na rynkach międzybankowych na świecie, a tym samym w Unii Europejskiej. Wynikało to przede wszystkim z faktu, że banki państw członkow- 
skich UE są silnie powiązane $\mathrm{z}$ bankami amerykańskimi, a więc wszelkie zachwiania na amerykańskim rynku finansowym miały bezpośredni wpływ na zmiany na rynku europejskim. Problemy zaufania do banków europejskich pogłębiły się pod wpływem kryzysu zadłużeniowego niektórych państw unijnych. Wynikało to $\mathrm{z}$ tego, że banki na dużą skalę finansowały rządy krajów strefy euro. Dlatego też ryzyko upadłości Grecji oraz wysokie zadłużenie chociażby Irlandii spowodowały, że inwestorzy mieli coraz mniejsze zaufanie do europejskich banków.

Drugim obliczem współczesnego kryzysu ekonomicznego w Unii Europejskiej był kryzys finansów publicznych. Pojawił się on w efekcie wpływu współczesnego kryzysu ekonomicznego na stan finansów publicznych państw członkowskich. Podstawowym zagrożeniem dla finansów publicznych, w warunkach panującego kryzysu, jest niebezpieczeństwo niskiej dynamiki wzrostu dochodów budżetowych lub też gwałtownego zmniejszania się tych dochodów. Dlatego też istotnym elementem jest równoważenie budżetu, ponieważ z jednej strony spadkowi ulegają dochody budżetowe, a $\mathrm{z}$ drugiej pojawia się presja na zwiększenie wydatków socjalnych. Następstwem tych zdarzeń jest zwiększenie się poziomu deficytu budżetowego (Sierak 2011, s. 115-116). Zbyt wysoki poziom deficytu budżetowego stanowi znaczne zagrożenie dla stabilności finansów publicznych zarówno w krótkim, jak i długim okresie. Najlepszym przykładem zbyt luźno prowadzonej polityki fiskalnej jest Grecja, w której przez lata wydatki budżetowe nadmiernie przekraczały dochody. W związku z tym deficyt budżetowy rokrocznie się powiększał, a to przełożyło się na wzrost zadłużenia publicznego i w konsekwencji mogło przyczynić się do upadłości tego państwa.

Odpowiedzią na wciąż rosnącą recesję w państwach członkowskich UE było zwiększenie roli polityki fiskalnej, co z jednej strony przyczyniło się do wyhamowania recesji, ale z drugiej doprowadziło do bardzo silnego wzrostu deficytu budżetowego. Dynamicznie rosnący deficyt finansów publicznych i dług publiczny, zwłaszcza krajów strefy euro, wzbudził obawy o długoterminową wypłacalność tych państw, a jednocześnie zmniejszył wiarygodność stosowania wsparcia publicznego udzielanego zagrożonym instytucjom finansowym (Ostaszewski 2013, s. 92). Dlatego też kraje strefy euro stanęły przed koniecznością zredukowania nadmiernego deficytu sektora finansów publicznych i długu publicznego. Jednocześnie rynki i inwestorzy przestali w pełni ufać państwom o nadmiernym zadłużeniu publicznym, a to ma wpływ na trudności z refinansowaniem zadłużenia. W efekcie banki z krajów strefy euro zagrożonych upadłością mają duże problemy z uzyskiwaniem finansowania rynkowego.

Obecny kryzys fiskalny jest zasadniczym problemem Unii Europejskiej. Obejmuje on przede wszystkim tak zwane państwa PIIGS, czyli Portugalię, Irlandię, Włochy, Grecję i Hiszpanię. Wszystkie te kraje naruszyły jeden z wymogów związanych z wprowadzeniem wspólnej waluty euro, czyli maksymalnie 3-procentowy udział deficytu budżetowego w produkcie krajowym brutto. Rządy tych państw w nieumiejętny oraz nieracjonalny sposób prowadziły politykę fi- 
skalną, a przez to doprowadziły je do znacznego zadłużenia publicznego (Guzek 2012, s. 309; Kraciuk 2013, s. 130). W rzeczywistości ciągły wzrost wydatków (np. na cele socjalne) w stosunku do wpływów (np. z podatków) budżetowych i równoczesne finansowanie aktualnych zobowiązań ze sprzedaży obligacji państwowych przekładało się na nieprzestrzeganie kryteriów fiskalnych zawartych w Traktacie o Unii Europejskiej. Finansowanie aktualnych zobowiązań państwa za pomocą obligacji państwowych było o tyle trudne, że agencje ratingowe uznały kraje PIIGS za zagrożone kryzysem, co odbiło się w negatywny sposób na poziomie oprocentowania obligacji (zaczęło spadać) i zaciąganych kredytów (zaczęło wzrastać).

Dotychczas wprowadzone w Unii Europejskiej rozwiązania takie jak udzielenie wsparcia finansowego Portugalii i Irlandii oraz umorzenie części długu Grecji, w zamian za wprowadzenie w tych krajach reform gospodarczych, stanowią jedynie działania tymczasowe. Wprowadzenie reform w tych państwach, szczególnie w Grecji, było i będzie niewątpliwie trudnym zadaniem. Na przykład w Grecji, gdy zaczęto wprowadzać radykalne i konieczne reformy gospodarcze, od których uzależniona była dalsza pomoc finansowa z UE, tamtejsze społeczeństwo zaczęło protestować przeciwko koniecznym i planowanym oszczędnościom (Kraciuk 2013, s. 131; Pacuła 2011, s. 144). Protesty te mogą świadczyć o tym, że socjalny model państwa, który nie jest uodporniony na kryzys, był i nadal jest dość popularny w zachodnim społeczeństwie. Podejmowane na szczeblu unijnym działania mające na celu pomoc państwom zagrożonym upadłością są tylko tymczasowe, ponieważ jeśli państwa te same nie zaczną wprowadzać reform gospodarczych, to żadna pomoc z zewnątrz nie będzie dostatecznie skuteczna.

Za najważniejsze przyczyny rosnącej niestabilności fiskalnej w krajach strefy euro można uznać:

1) procykliczny charakter prowadzonej polityki fiskalnej umiejscowionej pomiędzy dwoma kryzysami w Stanach Zjednoczonych — czyli z końcem kryzysu dotcomów z 2000 roku i początkiem kryzysu na amerykańskim rynku nieruchomości z 2007 roku;

2) wzrost kosztów kryzysu gospodarczego, które państwa ponosiły w związku z rządowymi działaniami na rzecz ratowania instytucji finansowych i banków zagrożonych upadłością;

3) trwająca na przestrzeni lat 2008-2009 w większości rozwiniętych krajów ogólnoświatowa recesja gospodarcza, która spowodowała zwiększenie wydatków publicznych i ograniczenie wpływów budżetowych z tytułu podatków;

4) zakończenie hossy na rynku aktywów (zwłaszcza na rynku nieruchomości) i normalizacja zysków w sektorze finansowym (Filipiak, Fila 2012, s. 42).

To właśnie połączenie wymienionych przyczyn ze specyficznymi uwarunkowaniami gospodarczymi poszczególnych państw UE przyczyniło się do pojawienia poważnych, negatywnych konsekwencji w sektorze finansów publicznych. $\mathrm{W}$ literaturze przedmiotu można znaleźć, że „W walce z kryzysem zadłużenia 
można zastosować dwie metody. Obie niestety charakteryzują się negatywnymi konsekwencjami. Dodruk pieniędzy w Stanach Zjednoczonych prowadzi do inflacji, natomiast ograniczanie wydatków, dyscyplina budżetowa w Unii Europejskiej ogranicza popyt i obniża wzrost PKB" (Matusewicz 2012, s. 23). Potwierdza to tezę, że aktualnie nie ma skutecznej metody walki ze skutkami kryzysu finansów publicznych.

\section{Grupa Wyszehradzka i poziom PKB państw wchodzących w jej skład}

Grupa Wyszehradzka (zwana też jako „Wyszehradzka Czwórka” lub „V4”) to nieformalne zrzeszenie czterech państw Europy Środkowej: Czech, Polski, Słowacji i Węgier. Celem jego założenia było pogłębienie współpracy pomiędzy wymienionymi państwami, w początkowej fazie procesu dotyczącego szczególnie kwestii przystąpienia do Unii Europejskiej oraz Paktu Północnoatlantyckiego (NATO). Obecnie celem Grupy Wyszehradzkiej jest pogłębienie współpracy w ramach członkostwa w UE, zwłaszcza w obszarach ważnych dla Europy Środkowo-Wschodniej. Współpraca pomiędzy państwami tworzącymi grupę jest istotnym czynnikiem wpływającym na możliwość oceny stanu ich finansów publicznych w okresie współczesnego załamania gospodarczego. Współpraca rozwijana jest w następujących obszarach (BSMiUE 2012, s. 14-15):

— współpraca w ramach V4,

- współpraca w ramach UE,

— współpraca z innymi partnerami,

— współpraca w ramach NATO i pozostałych organizacji międzynarodowych.

Współpraca w Grupie Wyszehradzkiej odbywa się przy wykorzystaniu następujących instrumentów (BSMiUE 2012, s. 15):

- rotacyjne roczne przewodnictwo - każde państwo przewodniczące Grupie przygotowuje własny program swojego przewodnictwa zapewniający, między innymi, ciągłość długoterminowej współpracy V4;

— jeden oficjalny szczyt premierów odbywający się corocznie, na zakończenie każdego kolejnego okresu przewodnictwa;

— okolicznościowe, a przy tym nieformalne spotkania premierów bądź też ministrów spraw zagranicznych, odbywające się przed ważnymi wydarzeniami międzynarodowymi;

— spotkania wiceministrów spraw zagranicznych, które poprzedzają oficjalne szczyty premierów;

- spotkania innych ministrów w grupie państw V4;

— zintensyfikowana komunikacja pomiędzy krajowymi koordynatorami V4 oraz ich kluczowa rola w wewnętrznej i międzypaństwowej koordynacji; 
— konsultacje i współpraca Stałych Przedstawicielstw przy UE i NATO w Brukseli, jak również na wszystkich innych forach (OBWE, ONZ, Rady Europy, OECD, WTO itp.);

- Międzynarodowy Fundusz Wyszehradzki oraz jego struktury.

Wykres na rysunku 1 przedstawia dynamikę zmian PKB w państwach Grupy Wyszehradzkiej.

\begin{tabular}{|c|c|c|c|c|c|c|c|}
\hline [w \%] & & & & & & & \\
\hline $\begin{array}{l}120,00 \\
115,00\end{array}$ & & & & & & & \\
\hline 110,00 & & & & & & & \\
\hline 105,00 & & & & $=$ & 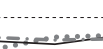 & $0 . \cdots \cdots$ & \\
\hline 95,00 & & & & 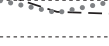 & -- & & \\
\hline 90,00 & $7=$ & & & & & & \\
\hline & & & & & & & \\
\hline & 2009 & 2010 & 2011 & 2012 & 2013 & 2014 & 2015 \\
\hline ---- Czechy & 92,17 & 105,40 & 104,91 & 98,41 & 97,71 & 99,31 & 106,58 \\
\hline ....... Węgry & 87,13 & 104,83 & 102,55 & 98,28 & 102,32 & 102,93 & 104,33 \\
\hline — Polska & 86,59 & 114,09 & 105,10 & 102,39 & 101,37 & 104,12 & 104,11 \\
\hline -.--S Słowacja & 96,93 & 105,59 & 104,54 & 102,81 & 101,95 & 102,34 & 103,32 \\
\hline
\end{tabular}

Rysunek 1. Dynamika zmian PKB w państwach V4 w okresie współczesnego kryzysu ekonomicznego

Źródło: opracowanie własne na podstawie (Eurostat 2016).

W 2009 roku w porównaniu z rokiem 2008 wystąpił we wszystkich analizowanych gospodarkach spadek PKB, co było spowodowane najprawdopodobniej tym, że wtedy w Unii Europejskiej oraz w poszczególnych jej państwach członkowskich pojawił się kryzys ekonomiczny. Współczesny kryzys gospodarczy i finansowy doprowadził do zahamowania rozwoju gospodarczego poszczególnych państw unijnych, w tym również tych tworzących Grupę V4. W grupie czterech państw Europy Środkowej, to Słowacja charakteryzowała się w badanych latach najstabilniejszą zmianą PKB, ponieważ poza 2009 rokiem, w którym wystąpił spadek o 3,07\%, występował w tym państwie ciągły wzrost tego wskaźnika makroekonomicznego. Przy czym najwyższy wzrost w porównaniu $\mathrm{z}$ rokiem poprzednim wystąpił w 2010 roku. Mianem państwa z najstabilniejszą zmianą PKB w Grupie Wyszehradzkiej można by określić Polskę, gdyby nie spadek tego wskaźnika o 13,41\% w 2009 roku i późniejszy wzrost w 2010 roku o 14,09\%. Tak duży spadek PKB w 2009 roku spowodowany był zapewne tym, że pojawienie się kryzysu ekonomicznego w UE było w pierwszej chwili szokiem dla polskiej gospodarki oraz dla jej zagranicznych inwestorów. Natomiast w 2010 roku nastąpił znaczny wzrost, gdyż okazało się, że rozprzestrzeniający się w państwach członkowskich kryzys 
ekonomiczny odczuwalny był w najmniejszym stopniu w Polsce. Jednocześnie spowodowało to powrót zagranicznych inwestorów do polskiej gospodarki, przyczyniając się do jej ciągłego rokrocznego rozwoju i wzrostu. Pod względem dynamiki zmian PKB za najmniej stabilną gospodarkę należy uznać Czechy, w których wystąpił spadek tego wskaźnika w 2009 roku o prawie $8 \%$, a także w mniejszym stopniu w latach 2012-2014. Wynikało to zapewne z faktu, że w latach 2012-2014 w Czechach doszło do zahamowania rozwoju gospodarczego wywołanego przez pojawienie się nowych skutków współczesnego kryzysu ekonomicznego.

\section{Wpływy, wydatki i budżet w państwach Grupy Wyszehradzkiej w latach 2007-2013}

Powyższe scharakteryzowanie wskaźnika PKB w państwach Grupy Wyszehradzkiej było wstępem do głównych analiz niniejszego artykułu, czyli do oceny ich stanu finansów publicznych. W pierwszej kolejności analizie zostały poddane wpływy oraz wydatki budżetowe, co przedstawiają tabela 1 oraz wykresy na rysunkach 2 i 3.

Tabela 1. Wpływy i wydatki budżetowe w państwach V4 w okresie współczesnego kryzysu ekonomicznego

\begin{tabular}{c|c|c|c|c|c|c|c|c|c}
\hline \multicolumn{2}{c|}{ Wyszczególnienie } & \multicolumn{7}{c}{ Rok } \\
\hline Gospodarka & \% PKB & 2008 & 2009 & 2010 & 2011 & 2012 & 2013 & 2014 & 2015 \\
\hline \multirow{2}{*}{ Czechy } & $\begin{array}{c}\text { wpływy } \\
\text { budżetowe }\end{array}$ & 38,1 & 38,1 & 38,6 & 40,4 & 40,7 & 41,6 & 40,8 & 42,2 \\
\cline { 2 - 11 } & $\begin{array}{c}\text { wydatki } \\
\text { budżetowe }\end{array}$ & 40,2 & 43,6 & 43,0 & 43,2 & 44,7 & 42,8 & 42,8 & 42,6 \\
\hline \multirow{2}{*}{ Węgry } & $\begin{array}{c}\text { wpływy } \\
\text { budżetowe }\end{array}$ & 45,1 & 46,1 & 45,0 & 44,3 & 46,3 & 47,0 & 47,5 & 48,7 \\
\hline $\begin{array}{c}\text { wydatki } \\
\text { budżetowe }\end{array}$ & 48,8 & 50,7 & 49,6 & 49,7 & 48,6 & 49,6 & 49,8 & 50,7 \\
\hline $\begin{array}{c}\text { wpływy } \\
\text { budżetowe }\end{array}$ & $\begin{array}{c}\text { wydatki } \\
\text { budżetowe }\end{array}$ & 40,9 & 38,0 & 38,1 & 38,8 & 38,9 & 38,4 & 38,9 & 38,9 \\
\hline \multirow{2}{*}{ Słowacja } & $\begin{array}{c}\text { wpływy } \\
\text { budżetowe }\end{array}$ & 34,3 & 36,1 & 34,5 & 36,4 & 36,2 & 38,6 & 39,2 & 42,7 \\
\hline & $\begin{array}{c}\text { wydatki } \\
\text { budżetowe }\end{array}$ & 36,7 & 43,9 & 42,0 & 40,5 & 40,5 & 41,3 & 41,9 & 45,6 \\
\hline
\end{tabular}

Źródło: opracowanie własne na podstawie (Eurostat 2016).

W badanych latach wpływy budżetowe w państwach V4 kształtowały się na podobnym poziomie nieprzekraczającym 50\% PKB. Na Węgrzech udział wpływów budżetowych w PKB był najwyższy i od 2012 roku rokrocznie wzrastał, a w 2015 roku osiągnął wartość prawie 50\%. Wynikało to z wprowadzanych zmian 
w systemie podatkowym, takich jak np. zwiększenie stawek podatkowych oraz przygotowywanie gospodarki do wprowadzenia 27\% stawki podatku od towarów i usług (VAT). Jednocześnie spośród wszystkich państw tworzących Grupę Wyszehradzką najniższy udział wpływów budżetowych w PKB wystąpił w Polsce, gdzie nie przekraczał 39\% (z wyjątkiem roku 2008, gdy wynosił 40,9\% PKB). Przy czym w Czechach i Polsce udział wpływów budżetowych w PKB był dość zbliżony i utrzymywał się na poziomie około 40\%. Na Słowacji natomiast wpływy budżetowe wzrosły z 34,3\% PKB w 2008 roku do 42,7\% w roku 2015. Wzrost dochodów budżetowych wynikał z poprawiającej się rokrocznie sytuacji ekonomicznej gospodarki słowackiej.

Wydatki budżetowe we wszystkich państwach V4 kształtowały się w badanych latach na poziomie 40-50\%, przy czym w 2008 roku na Słowacji stanowiły mniej niż 40\% PKB. Najwyższy procentowy udział wydatków budżetowych w PKB wystąpił na Węgrzech, gdzie był zbliżony do 50\% lub nieznacznie przekraczał tę wielkość (2009 i 2015 rok), a najniższy w Czechach, gdzie nie przekraczał 45\%. W Polsce wydatki budżetowe wzrosły w latach 2009-2010, natomiast od 2011 roku występował ich spadek. Wydatki budżetowe stanowiły około 45\% polskiego PKB. Procentowo wydatki budżetowe wszystkich państw Grupy Wyszehradzkiej mają podobny udział w PKB, natomiast wartościowo najwyższe wydatki budżetowe występowały w Polsce. Wynikało to z faktu, że polska gospodarka była i jest najlepiej rozwijającą się spośród państw tworzących Grupę. Czeskie wydatki budżetowe były ponad dwukrotnie, węgierskie ponad trzykrotnie, a słowackie prawie siedmiokrotnie, niższe niż w Polsce. Różnice te wynikały przede wszystkim z wielkości gospodarek państw Grupy Wyszehradzkiej oraz z poziomu rozwoju gospodarczego tych państw.

\begin{tabular}{|c|c|c|c|c|c|c|c|}
\hline [w \%] & & & & & & & \\
\hline $\begin{array}{l}120,00 \\
115,00\end{array}$ & & & & & & & \\
\hline $\begin{array}{l}110,00 \\
105,00\end{array}$ & & & & & $1-1$ & & \\
\hline 100,00 & & & & & & & \\
\hline 90,00 & & & & & & & \\
\hline & & & & & & & \\
\hline 80,00 & & & & & & & \\
\hline & 2009 & 2010 & 2011 & 2012 & 2013 & 2014 & 2015 \\
\hline ---- Czechy & 92,30 & 106,64 & 109,69 & 99,00 & 99,65 & 96,81 & 109,50 \\
\hline ....... Węgry & 88,96 & 102,42 & 100,85 & 102,75 & 103,97 & 104,02 & 106,87 \\
\hline — Polska & 80,39 & 115,32 & 106,93 & 102,72 & 100,03 & 105,49 & 104,12 \\
\hline -.--S Słowacja & 101,88 & 101,00 & 110,28 & 102,30 & 108,65 & 104,03 & 112,34 \\
\hline
\end{tabular}

Rysunek 2. Dynamika zmian wpływów budżetowych w państwach Grupy Wyszehradzkiej w okresie współczesnego kryzysu ekonomicznego

Źródło: opracowanie własne na podstawie (Eurostat 2016). 
Wykres na rysunku 2 przedstawia dynamikę zmian wielkości wpływów budżetowych w badanych latach, która kształtowała się w podobny sposób jak w przypadku PKB. Mianowicie prawie wszystkie kraje Grupy Wyszehradzkiej w 2009 roku odnotowały spadek wielkości wpływów budżetowych w porównaniu z rokiem poprzednim. Wyjątek stanowiła Słowacja, w której wystąpił nieznaczny wzrost o 1,88\%. Spadek wpływów budżetowych w państwach V4 wynikał przede wszystkim z faktu, że współczesny kryzys ekonomiczny, który wtedy pojawił się w Unii Europejskiej, wpłynął negatywnie na gospodarki jej państw członkowskich. Wywołał on między innymi spadek dochodów obywateli, a przez to mniejsza była wartość wpływu z podatków dochodowych. Jednocześnie spadek dochodów obywateli wywołał zmniejszenie konsumpcji i spadek wielkości podatków pośrednich - głównie podatku od towarów i usług (VAT). Podatki te są podstawowym źródłem dochodów budżetu, dlatego też ich spadek wywołał zmniejszenie wielkości wpływów budżetowych w porównaniu z rokiem poprzednim. Najbardziej stabilne wpływy budżetowe można odnotować na Słowacji, gdzie w latach 2009-2015 występował rokroczny wzrost wpływów budżetowych, a największy o 12,34\% w roku 2015. Tak stabilna dynamika wpływów budżetowych na Słowacji mogła wynikać z tego, że w tamtejszym systemie podatkowym nie były dokonywane w badanych latach radykalne zmiany. Ponadto kryzys, który w 2009 roku dotknął państwa unijne, nieznacznie wpłynął na sytuację ekonomiczną Słowaków, ale nie spowodował aż tak dużego spadku wpływów do budżetu. W Polsce w badanych latach wystąpił dość znaczny spadek wpływów budżetowych w roku 2009, prawie o 20\%. Tak znaczny spadek wynikał z faktu, że pojawienie się kryzysu ekonomiczego w UE wpłynęło na obniżenie dochodów Polaków oraz zmniejszenie konsumpcji na rzecz oszczędności. Natomiast od 2010 roku występował rokroczny wzrost wpływów, a największy o 15,32\% w roku 2010. Taka sytuacja była wynikiem tego, że kryzys ekonomiczny w rzeczywistości ominął polską gospodarkę (jako jedyną w UE), a to spowodowało ponowny napływ inwestorów oraz wzrost konsumpcji. Ponadto od 2009 roku w Polsce występują dwa progi podatkowe w podatku dochodowym od osób fizycznych, podczas gdy w latach wcześniejszych były trzy. Wprowadzenie tej zmiany w 2009 roku przyczyniło się do uproszczenia opodatkowania osób fizycznych, a przy tym zwiększenia wpływów podatkowych do budżetu. Ciekawie wyglądała też sytuacja na Węgrzech, gdzie w 2009 roku wystąpił, podobnie jak w Polsce, znaczny spadek wpływów budżetowych - o 11,04\% w porównaniu z 2008 rokiem. Spadek ten odzwierciedla wpływ kryzysu ekonomiczego na stan węgierskiej gospodarki. W kolejnych latach nastąpił natomiast wzrost wpływów budżetowych, podobnie jak w Polsce. Przy czym w 2011 roku wzrost ten był nieznaczny, bo zaledwie o $0,85 \%$. Było to spowodowane tym, że w roku 2011 na Węgrzech dokonywane były znaczne zmiany w systemie podatkowym, co przełożyło się na wzrost wielkości podatków, aczkolwiek dało to nieznaczny wzrost wpływów budżetowych. Natomiast od 2012 roku wielkość wpływów do budżetu rokrocznie wzrastała, było to efektem podwyższenia podstawowej stawki VAT aż do $27 \%$, co miało po- 
móc poprawić kondycję węgierskich finansów publicznych. Najmniej stabilny stan wpływów budżetowych występował w badanych latach w Czechach, gdzie wzrosty były przeplatane spadkami. W roku 2009 wystąpił największy spadek o 7,70\% w porównaniu z rokiem wcześniejszym, co było efektem wpływu skutków kryzysu ekonomicznego na tamtejszą gospodarkę i społeczeństwo. Kolejne spadki wystąpiły w latach 2012-2014, przy czym w okresie 2012-2013 o około 1\%, a w 2014 ponad 3\%. Wzrost wpływów budżetowych występował zaś w latach 2010-2011 i w 2015 roku. Największe wpływy o ponad 9\% wystąpiły w latach 2011 i 2015. W 2011 roku były one spowodowane poprawą stanu gospodarki, gdyż kryzys ekonomiczny tylko nieznacznie wpłynął na jej stan. Natomiast wzrost w 2015 roku był już wynikiem przeprowadzonych reform w systemie podatkowym oraz zwiększeniem inwestycji krajowych i zagranicznych.

\begin{tabular}{|c|c|c|c|c|c|c|c|}
\hline [w \%] & & & & & & & \\
\hline $\begin{array}{l}120,00 \\
115,00\end{array}$ & & & & & & & \\
\hline $\begin{array}{l}110,00 \\
105,00\end{array}$ & & & & & & & \\
\hline $\begin{array}{r}100,00 \\
95,00\end{array}$ & & & & & & & \\
\hline 90,00 & $.0 \%$ & & & & & & \\
\hline 85,00 & & & & & & & \\
\hline & 2009 & 2010 & 2011 & 2012 & 2013 & 2014 & 2015 \\
\hline ---- Czechy & 100,11 & 103,83 & 105,07 & 101,72 & 93,59 & 98,46 & 105,54 \\
\hline ....... Węgry & 90,52 & 102,50 & 102,96 & 96,03 & 104,50 & 103,33 & 106,16 \\
\hline$\longrightarrow$ Polska & 88,05 & 115,82 & 100,46 & 99,96 & 100,94 & 103,61 & 102,38 \\
\hline -.-.-Słowacja & 116,18 & 100,86 & 100,86 & 102,89 & 103,88 & 103,92 & 112,44 \\
\hline
\end{tabular}

Rysunek 3. Dynamika zmian wydatków budżetowych w państwach Grupy Wyszehradzkiej w okresie współczesnego kryzysu ekonomicznego

Źródło: opracowanie własne na podstawie (Eurostat 2016).

Wykres na rysunku 3 przedstawia dynamikę zmian wydatków budżetowych, która kształtowała się w badanych latach inaczej aniżeli w przypadku wpływów do budżetu. W państwach V4 najbardziej zauważalny jest rokroczny wzrost wydatków budżetowych na Słowacji. W 2009 roku wzrost ten był znaczny, bo przekraczał 16\%, natomiast w kolejnych pięciu latach nie przekraczał 4\%, a w 2015 roku wyniósł ponad $12 \%$. Pojawienie się kryzysu ekonomicznego w UE przyczyniło się do ciągłego wzrostu wydatków z budżetu słowackiego, gdyż środki te były przeznaczane na rozwój gospodarki i zwiększenie jej wzrostu. W Czechach wzrost wydatków budżetowych występował w latach 2009-2012 (najniższy wzrost o 0,11\% w roku 2009, najwyższy zaś w 2011 o 5,07\%), natomiast w 2013 i 2014 roku wystąpił spadek odpowiednio o 6,41\% (2013 rok) i 1,54\% (2014 rok). W roku 2015 wystąpił ponownie wzrost wydatków o ponad 5\% w porównaniu z 2014 rokiem. 
Wzrost wydatków budżetowych w Czechach był podobnie jak na Słowacji uzależniony od dążenia rządu do rozwoju gospodarki oraz przyśpieszenia jej wzrostu. Występujące spadki wynikały z próby obniżenia wydatków budżetowych w celu obniżenia deficytu budżetowego i długu publicznego. W Polsce znaczny spadek wydatków budżetowych o prawie $12 \%$ wystąpił w roku 2009 w porównaniu z 2008 i wynikał ze znacznego spadku wpływów budżetowych, za pomocą których można by sfinansować planowane wydatki budżetowe. Natomiast największy wzrost wystąpił w roku 2010, bo o 15,82\% i wynikał z wprowadzonego już w pełni programu antykryzysowego, w którym chociażby przewidziano zwiększenie wydatków socjalnych oraz wsparcie dla przedsiębiorstw najbardziej zagrożonych negatywnymi skutkami kryzysu. W kolejnych latach występował wzrost wydatków w granicach od 0,5\% w 2011 roku do 3,61\% w 2014 roku. Aczkolwiek w roku 2012 wystąpił bardzo niewielki, bo zaledwie o 0,04\% spadek wpływów budżetowych. Sytuacja na Węgrzech w badanym okresie miała tendencję podobną do Polski, mianowicie w 2009 roku wystąpił znaczny spadek o 9,48\%, a drugi o prawie 4\% w 2012 roku. Spadek w 2009 roku wynikał z faktu, że wystąpił wtedy również spadek wielkości wpływów do budżetu, a zatem rząd musiał zmniejszyć wielkość wydatków, aby pokryć je mniejszymi wpływami. W latach 2010-2011 i 2013-2015 występował wzrost wydatków, a największy o ponad 6\% w 2015 roku. Wzrosty w pierwszych dwóch latach były przede wszystkim wynikiem wprowadzanego programu antykryzysowego. Natomiast w kolejnych trzech latach były spowodowane wzrostem wpływów budżetowych, dzięki którym można było zwiększyć wydatki na poprawienie gospodarki węgierskiej.

$\left[\begin{array}{l}{[\mathrm{w} \%]} \\ 0,0 \\ -1,0 \\ -2,0 \\ -3,0 \\ -4,0 \\ -5,0 \\ -6,0 \\ -7,0\end{array}\right]$
$-8,0$
$-9,0$

Rysunek 4. Deficyt/nadwyżka budżetu jako procent PKB w państwach Grupy Wyszehradzkiej w okresie współczesnego kryzysu ekonomicznego

Źródło: opracowanie własne na podstawie (Eurostat 2016). 
Kolejną analizowaną pozycją będzie deficyt/nadwyżka budżetu w państwach Grupy Wyszehradzkiej, co przedstawia wykres na rysunku 4. Państwa tworzące Grupę Wyszehradzką miały w badanych latach problem z przestrzeganiem kryterium deficytu budżetowego, które zakłada, że nie może on być wyższy niż 3\% PKB. Najlepiej kryterium to spełniały Czechy, gdzie nie było przestrzegane wyłącznie w latach 2009-2010 i 2012. Największa wartość deficytu budżetowego wynosząca 5,5\% występowała w 2009 roku i była wynikiem dużego spadku wpływów budżetowych wywołanego przez kryzys ekonomiczny. Najniższa wartość deficytu wystąpiła w roku 2015 i wynosiła zaledwie $0,4 \%$ czeskiego PKB, co było spowodowane tym, że wpływy i wydatki budżetowe osiągnęły w tym roku prawie identyczną wartość. Na Węgrzech kryterium trzyprocentowego deficytu budżetowego nie było przestrzegane w latach 2008-2011 (najwyższy poziom 5,4\% w 2011 roku), co było spowodowane zwiększeniem wydatków budżetowych niezbędnych do wsparcia gospodarki dotkniętej kryzysem. Natomiast w latach 2012-2015 deficyt budżetowy był niższy niż 3\% (najniższy poziom 2,0\% w 2015 roku), co było spowodowane większym wzrostem wpływów budżetowych wynikających z wprowadzonych reform w systemie podatkowym. W Polsce deficyt budżetowy poniżej 3\% PKB występował w badanych latach wyłącznie w 2015 roku i wynosił $2,6 \%$. W pozostałych latach był on wyższy, a najwyższą wartość ponad 7\% uzyskał w latach 2009-2010, co było wynikiem dwóch czynników. Po pierwsze, wpływy budżetowe w Polsce uległy dużemu spadkowi wywołanemu ograniczeniem przez społeczeństwo konsumpcji na rzecz oszczędności. Po drugie, wzrostowi uległy wydatki budżetowe przewidziane w ramach wprowadzanego programu antykryzysowego, które miały poprawić polską gospodarkę i przyśpieszyć jej wzrost. Na Słowacji deficyt budżetowy poniżej 3\% PKB był utrzymywany w roku $2008 \mathrm{i}$ w latach 2013-2015, przy czym najniższy poziom wynoszący 2,4\% wystąpił w roku 2008. Natomiast w latach 2009-2012 występował deficyt przekraczający $3 \%$ PKB, a najwyższa jego wartość przypadała na lata 2009-2010 i wynosiła ponad 7\%. Taki wysoki deficyt budżetowy w tych latach był spowodowany znacznym wzrostem wysokości wydatków budżetowych, zwłaszcza w 2009 roku, na co wpływało wprowadzanie programu naprawy gospodarki słowackiej.

\section{Dług publiczny w państwach Grupy Wyszehradzkiej}

Ostatnim elementem związanym ze stanem finansów publicznych państw Grupy Wyszehradzkiej, który zostanie przeanalizowany, jest wielkość długu publicznego tych państw, co przedstawia wykres na rysunku 5. 


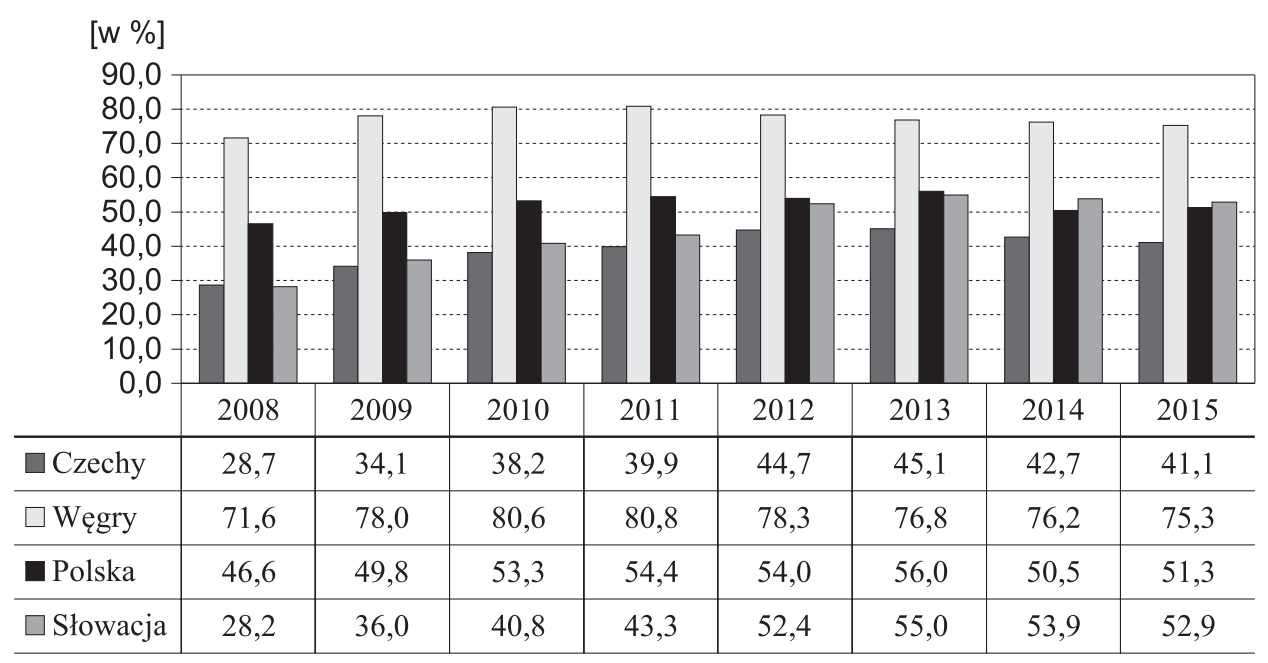

Rysunek 5. Dług publiczny jako procent PKB w państwach Grupy Wyszehradzkiej w okresie współczesnego kryzysu ekonomicznego

Źródło: opracowanie własne na podstawie (Eurostat 2016).

Założenia fiskalne kryterium konwergencji zakładają, że aby móc przyjąć wspólną walutę euro, niezbędne jest posiadanie deficytu budżetowego na poziomie niższym niż 3\% PKB, oraz długu publicznego nieprzekraczającego 60\% PKB. Wśród państw V4 warunku drugiego w badanym okresie nie przestrzegały wyłącznie Węgry, których dług publiczny znacznie przekraczał ustaloną granicę, a w latach 2010-2011 kształtował się nieznacznie powyżej 80\% PKB. Tak wysoka wartość relacji długu publicznego do PKB wynikała prawdopodobnie z nieumiejętnego prowadzenia tamtejszej polityki fiskalnej bądź też z niespłaconych dotąd kredytów zagranicznych, na których nowe raty rząd węgierski musiał się zapożyczać u społeczeństwa. Polski dług publiczny natomiast wahał się w badanych latach w przedziale 46-56\% PKB, przy czym w latach 2008-2013 praktycznie rokrocznie wzrastał (wyjątek 2012 rok — spadek), a w kolejnych dwóch latach uległ zmniejszeniu. Polska zatem w badanych latach przestrzegała warunku relacji długu publicznego do PKB na poziomie niższym niż $60 \%$. Pomimo przestrzegania tego kryterium w lipcu 2013 roku polskie władze postanowiły zawiesić obowiązywanie I progu ostrożnościowego. W latach 2009-2015 w Czechach dług publiczny był niższy niż 50\% PKB. Wśród państw Grupy Wyszehradzkiej to właśnie czeski dług publiczny kształtował się na najniższym poziomie na przestrzeni badanych lat. W państwie tym dług publiczny wzrósł w tym czasie z 28,7\% PKB w 2008 roku do 45,1\% PKB w roku 2013, by następnie spaść do 41,1\% w 2015 roku. Wartość tego wskaźnika poniżej 50\% świadczy o tym, że w Czechach prowadzono dość stabilną politykę fiskalną. Na Słowacji dług publiczny również był w początkowych latach badanego okresu na niskim poziomie, tyle że w odróżnieniu od Czech rokrocznie wzrastał. W roku 2013 był on już 
prawie dwukrotnie wyższy niż w roku 2008. Tak duży wzrost tego wskaźnika mógł wynikać z dwóch powodów. Po pierwsze, polityka fiskalna na Słowacji była prowadzona w miarę dobrze, ale nie do końca spełniała ona swoje zadania. Po drugie, taki wzrost relacji długu publicznego do PKB mógł wynikać z podobnych przesłanek jak w przypadku Węgier, czyli z niespłaconych kredytów zaciągniętych u innych państw, na których kolejne raty władze słowackie musiały zapożyczać się u swych obywateli.

\section{Wnioski}

W 2009 roku, gdy do Unii Europejskiej zawitał kryzys ekonomiczny, znacznemu wzrostowi uległ deficyt budżetowy w państwach Grupy Wyszehradzkiej. W Czechach deficyt budżetowy wzrósł w 2009 roku w porównaniu z 2008 o 3,4\%, w Polsce o 3,7\%, na Słowacji o 5,4\%, a na Węgrzech o 0,9\%. Tak niski wzrost węgierskiego deficytu budżetowego był spowodowany głównie tym, że już przed 2009 rokiem deficyt budżetowy tego państwa osiągnął dosyć wysoki poziom. W pozostałych państwach wzrost i to dość znaczny wynikał z tego, iż pojawienie się kryzysu wywołało zachwianie systemów gospodarczych Czech i Słowacji oraz spowolnienie gospodarki w Polsce, na co rządy tych państw zareagowały wprowadzaniem pakietów antykryzysowych. Wywołało to zmniejszenie wpływów budżetowych a zwiększenie wydatków i w ostateczności zwiększenie deficytu. W latach 2008-2015 Polska była jedynym spośród państw V4, w którym praktycznie nie przestrzegano w całym okresie deficytu budżetowego na poziomie niższym niż 3\% PKB. Taka sytuacja była wynikiem pojawienia się kryzysu ekonomicznego w UE i chociaż jego wpływ na polską gospodarkę okazał się mniejszy niż w innych państwach europejskich, to polski rząd podjął działania antykryzysowe zmierzające do zabezpieczenia gospodarki przed skutkami kryzysu i utrzymywanie dalszego wzrostu gospodarczego.

Dług publiczny w państwach tworzących Grupę Wyszehradzką w latach 2008-2015 kształtował się na różnym poziomie, przy czym w trzech państwach był on niższy niż zakładane w kryteriach konwergencji $60 \%$ PKB, a w jednym przekraczał tę wartość. Węgierski dług publiczny w badanym okresie kształtował się na poziomie $71-81 \%$ PKB, co oznacza, że znacznie przekraczał zakładane w kryteriach konwergencji $60 \%$. Wywołane było to najpewniej niespłaconymi jeszcze, wcześniej zaciągniętymi, zagranicznymi pożyczkami finansowymi. Na Słowacji dług publiczny wzrósł z 28,2\% w 2008 roku aż do 55\% w 2013 roku, by następnie spaść do 52,9\% w 2015 roku. Było to wynikiem, tak jak na Węgrzech, niespłaconych jeszcze pożyczek zagranicznych oraz poluzowaniem polityki fiskalnej państwa w okresie kryzysu, co miało na celu pobudzenie gospodarki słowackiej do dalszego wzrostu. Czeski dług publiczny w latach 2009-2013 nie przekraczał 50\% PKB, co spowodowane było zapewne spłaconymi już w większości 
pożyczkami zagranicznymi. Aczkolwiek w latach 2008-2013 w Czechach można odnotować tendencję wzrostową zadłużenia finansów publicznych, co może świadczyć o pewnym poluzowaniu dyscypliny finansów publicznych. Polski dług publiczny w latach 2008-2015 wzrósł z 46,6\% do 51,3\%, przy czym w 2013 roku wyniósł $56 \%$. Polska zatem spełniała w badanych latach jedno z fiskalnych kryteriów konwergencji. Taka wielkość polskiego długu publicznego wynikała głównie z niespłaconych jeszcze pożyczek zagranicznych ( $\mathrm{z}$ tak zwanego Klubu Paryskiego Polsce pozostały w tamtym okresie do spłacenia pożyczki od Japonii).

Spośród analizowanych państw Polska jest traktowana jako najlepiej rozwijające się gospodarczo państwo tej grupy, które zostało praktycznie ominięte przez kryzys ekonomiczny. Natomiast pod względem stanu finansów publicznych najlepiej wypadają tu Czechy, które obniżyły znacznie swój deficyt budżetowy w ostatnich latach, a także nieznacznie zadłużenie publiczne. Najgorszą kondycję finansów publicznych spośród państw V4 mają Węgry. Węgierski deficyt budżetowy kształtował się $\mathrm{w}$ badanych latach trochę lepiej niż słowacki, ale nadmierny dług publiczny powoduje, że węgierskie finanse publiczne są w trudniejszej sytuacji. Na tle pozostałych państw członkowskich UE kondycja sektora publicznego w tych czterech krajach Europy Środkowej nie jest jeszcze tak zła i daleko jej do sytuacji panującej w Grecji czy też we Włoszech.

Tak naprawdę wszystkie kraje Grupy Wyszehradzkiej wymagają reformy finansów publicznych, gdyż ich zadłużenie publiczne w połączeniu z deficytem budżetowym świadczy raczej o nie do końca stabilnej kondycji finansów publicznych. Główną przyczyną takiego stanu było pojawienie się w Unii Europejskiej kryzysu ekonomicznego w roku 2009, co wymusiło na państwach wprowadzenie programów antykryzysowych i poluzowanie finansów publicznych w celu ratowania ich sytuacji gospodarczej.

\section{Bibliografia}

Biuro Spraw Międzynarodowych i Unii Europejskiej (2012), Informacja na temat Grupy Wyszehradzkiej, Warszawa, Kancelaria Senatu.

Eurostat (2016), Eurostat Database, data dostępu 9.08.2016, http://ec.europa.eu/eurostat/data/database.

Filipiak B., Fila J. (red.) (2012), System finansowy a rozwój gospodarczy. Szanse i zagrożenia, Warszawa, Difin.

Firlej K. (2011), Źródła i przebieg kryzysu finansowego w Stanach Zjednoczonych i Europie Zachodniej, „Roczniki Ekonomiczne Kujawsko-Pomorskiej Szkoły Wyższej w Bydgoszczy” Nr 4 (2011), A. Czyżewski (red.), Bydgoszcz, Wydawnictwo Kujawsko-Pomorskiej Szkoły Wyższej w Bydgoszczy, s. 179-191.

Guzek M. (red.) (2012), Ekonomia i polityka w kryzysie. Kierunki zmian w teoriach, Warszawa, Uczelnia Łazarskiego Instytut Studiów Politycznych PAN.

Kraciuk J. (2013), Kryzys finansowy strefy euro, „Optimum. Studia Ekonomiczne” 2013, nr 4 (64), Wydawnictwo Uniwersytetu w Białymstoku, Białystok, s. 125-132. 
Lepczyński B., Penczar M. (2012), Wpływ globalnego kryzysu zaufania na pozycję polskiego sektora bankowego w Unii Europejskiej, „Zarządzanie i Finanse” 12, nr 4/1, Sopot, Wydział Zarządzania Uniwersytetu Gdańskiego, s. 401-418.

Luc S. (2011), Koordynacja polityki w Unii Europejskiej w obliczu kryzysu ekonomicznego, [w:] J. Stacewicz (red.), Polityka gospodarcza w świetle kryzysowych doświadczeń, „Prace i Materiały Instytutu Rozwoju Gospodarczego SGH”, nr 85, Warszawa, Szkoła Główna Handlowa w Warszawie - Oficyna Wydawnicza, s. 145-168.

Matusewicz M. (2012), Strefa euro a globalny kryzys finansowy XXI wieku, [w:] A. Gołębiowski (red.), Finanse Unii Europejskiej, „Studia Biura Analiz Sejmowych Kancelarii Sejmu”, nr 3 (31) 2012, Warszawa, Wydawnictwo Sejmowe Kancelarii Sejmu, s. 9-28.

Mesjasz L. (2012), Kryzys finansowy w państwach strefy euro: Zarządzanie i koncepcje przezwyciężenia, [w:] J. Bednarczyk (red.), W. Przybylska-Kapuścińska (red.), Polityka finansowa w dobie kryzysu integracji europejskiej, Warszawa, CeDeWu Sp. z o.o., s. 117-136.

Ostaszewski J. (red.) (2013), Finanse, Warszawa, Difin.

Pacuła P. (2011), Kryzys ekonomiczny w Europie a bezpieczeństwo Unii Europejskiej i Polski, „Bezpieczeństwo Narodowe" 1, 2011/17, Warszawa, Biuro Bezpieczeństwa Narodowego, s. 139-150.

Sierak J. (2011), Wplyw kryzysu na finanse publiczne państw Unii Europejskiej. Wybrane problemy, [w:] R. Bartkowiak (red.), J. Ostaszewski (red.), Ekonomia, nauki o zarządzaniu, finanse i nauki prawne wobec światowych przemian kulturowych, społecznych, gospodarczych i politycznych, Warszawa, Oficyna Wydawnicza Szkoła Główna Handlowa w Warszawie, s. 115-129. 